University of Wollongong

Research Online

Faculty of Arts - Papers (Archive)

Faculty of Arts, Social Sciences \& Humanities

January 2007

\title{
Liminality, temporality and marginalization in Giorgio Mangiamele's migrant movies
}

Gitano Rando

University of Wollongong, grando@uow.edu.au

Follow this and additional works at: https://ro.uow.edu.au/artspapers

Part of the Arts and Humanities Commons, and the Social and Behavioral Sciences Commons

\section{Recommended Citation}

Rando, Gitano, Liminality, temporality and marginalization in Giorgio Mangiamele's migrant movies 2007. https://ro.uow.edu.au/artspapers/163 


\title{
Liminality, temporality and marginalization in Giorgio Mangiamele's migrant movies
}

\author{
Gaetano Rando University of Wollongong
}

\author{
Modern Languages Programme \\ University of Wollongong \\ Northfields Ave, \\ Wollongong NSW 2522, \\ Australia \\ Tel: +61 242213644 \\ Email: grando@uow.edu.au
}

\begin{abstract}
:
Giorgio Mangiamele, born in Catania in 1926, migrated to Melbourne in 1952 and constitutes a rare example of CALD involvement in the early development of Australian cinema in the post-war period. His feature film Clay (1965) was the first Australian film to be invited to enter the competition at the Cannes Film Festival. However, despite his significant contribution to the emerging Australian cinematic culture, particularly to the development of 'art' cinema, he has received relatively little recognition. Over a thirty year period Mangiamele made fourteen films as director or director/producer. His first productions-The Contract (1953), Unwanted (ca 1957), The Brothers (1958), The Spag (1961) and Ninety-Nine Per cent (1963) - present themes related to the Italian migration experience in Australia in the 1950s depicted in all its immediacy and contemporaneity as an integral feature of the existentialist condition of our times. The only Australian director consistently to deal with such themes at the time, Mangiamele focuses on the dislocation, the alienation, the loneliness and the recall of the home country that constitutes the experience of his emblematic characters struggling to make sense of a society that is in many ways unaccepting. This paper proposes to apply the concepts of liminality and temporality elabourated by Hamid Nacify (2001) to the analysis of the themes related to the Italian Australian diaspora in the films of Giorgio Mangiamele.
\end{abstract}

Keywords: Giorgio Mangiamele; Australian cinema history; Cinema criticism; Migrant experiences; Marginalisation and ethnicity

Biography:

Gaetano Rando is Associate Professor in Italian Studies and English Language and Linguistics at the University of Wollongong. He has written extensively in Italian Australian studies, recent publications being: Emigrazione e letteratura: Il caso italoaustraliano, Cosenza: Luigi Pellegrini Editore, 2004; 'Italian Australian poetry by first generation writers: an overview,' JASL, 5 (2006), pp. 39-57; and Rosa R. Cappiello, Oh lucky country. Translated with an introduction by Gaetano Rando, Sydney: Sydney University Press, 2003 (Classic Australian Works series). 


\section{Liminality, temporality and marginalisation in Giorgio Mangiamele’s migrant movies ${ }^{1}$}

Gaetano Rando University of Wollongong

Giorgio Mangiamele (Catania 1926 - Melbourne 2001) migrated to Australia in 1952, bringing with him a passionate interest in film-making acquired in Italy (Ferlito 2006) and the idea of founding an Australian film industry. This was a clearly prophetic vision even if, despite undisputed skills as a director and cinematographer, Mangiamele’s contribution was largely to go unrecognised. He is generally considered the founder of 'art' cinema in Australia and his is the only Italian name included in John Baxter's (1970) seminal work on Australian cinema. Clay (Mangiamele, 1965), which relates the brief, tragic but intensely existential love story between the sculptor Margot and the fugitive Nick, wanted for murder, was the first Australian film to be invited in competition at the Cannes Film Festival, thus procuring for Australian cinema a first international artistic recognition. ${ }^{2}$

Later film historians and critics have been somewhat less generous and, although an annual film award is given in his memory by the Producers' and Directors' Guild of Victoria, he has been largely forgotten or excluded from most canons of Australian national cinema. He is also significantly absent from almost all the major critical texts. O’Regan (1996) only gives Mangiamele a brief mention with reference to Clay without considering the rest of his work. Two of Mangiamele’s feature films are listed without commentary in Verhoeven (1999) but there is no mention of him (or indeed other important non-Anglo film-makers) in Stewart (1984), Dermody and Jacka (1987 and 1988), or Murray (1994). Nor is he mentioned in more recent critical works which deal with Australian multicultural cinema by Stratton (1998) and Collins and Davis (2004).

While, as Turner has pointed out, Australian cinema and its critical literature have gone beyond what Chris Berry described as 'a token nod in the direction of multiculturalism and aboriginality,' (Turner 1994: 126) there is still no major study of Mangiamele’s work. 
The first major exposure of Mangiamele's films occurred at the First Italian Australian Film Festival in Sydney in May 2005, where screenings of Clay, The Spag (1961), and Ninety-Nine Percent (1963) were introduced by his widow Rosemary Mangiamele and ANU academic Gino Moliterno. There was also a round-table discussion which revealed an urgent need for more substantive research on Mangamele and his work: in the context of the Italian migrant experience on film; in terms of the influence of European cinema; and in order to retrieve and analyze important archival material related to his work. This urgency has been articulated not only in Australia but also in Italy where on 12 April 2005 the city of Catania hosted a retrospective of his work.

The few studies on Giorgio Mangiamele that have been produced are somewhat fragmentary and do not represent an in-depth and holistic view of his work, nor do they provide detailed analyses of his films, while the very few studies of Mangiamele's 'migrant' films do not take into account the Italian migrant experience of the time. Quentin Turnor's brief but insightful article (2001) places Mangiamele's work in the context of the state of Australian cinema in the 1950s arguing that his cinema was 'almost like a hyper-leap in a film-making future' with respect to other Australian productions at the time. In two slightly overlapping articles Lampugniani (2002 and 2005) examines the use of cinematographic images to depict the Italian-Australian migration experience in one version of The Spag and in Ninety-Nine Percent and articulates the sense of repudiation and alienation that constituted a significant aspect of that experience. But Lampugniani does not correlate Mangiamele's work to the real-life experience of the Italian migrant of the time. Lampugnani (2006) further examines Ninety-Nine Percent in the context of stereotypical comic depictions of Italian migrants in the 1950s, arguing that the director has 'created an effective filmic language through the appropriation of the dominant prejudicial assimilationist discourse of the time and 
the construct of Pirandellian humorist situations that are socially disturbing' (Lampugnani 2006: 22).

Tuccio (2005a) discusses Mangiamele’s marginialisation with reference to the work of Gunew and Hage but without placing it in its specific socio-cultural context. She also touches on Mangiamele's innovative contribution to the development of Australian cinema but does not substantiate how and to what extent Mangiamele's visual and oneric poetry influenced some Australian films of the 1970s (Tuccio 2005a: 107, 108). Mangiamele is also featured in some of the more generic studies on the impact of cultural difference in Australian cinema. Conomos (1992), for example, considers his work as fundamental in 'reading Australian cinema in terms of its multiple representations of the non-Anglo-Celtic migrant' without specifying in detail how, why and to what extent, while Alex Castro has suggested that Mangiamele was a 'father' of 'ethnic, migrant, multicultural or non-English speaking background (NESB) film-makers' (Castro 2000: 1) of the 1990s and he presents 'a unique figure in our national cinema.' (Castro 2000: 3). Interviews with and about Mangiamele such as Cutts (1992), Ditessa (2001) and Tuccio (2005b), bring to light some very interesting material but would profit from integration, cross-referencing and sifting for the occasional error of fact and/or interpretation, one specific example being Tuccio’s discussion relating to the reasons behind the choice of the theme for Sapos (Mangiamele, 1982).

This paper proposes an overview of Mangiamele’s cinematographic representation of the Italian migration experience in Melbourne during the 1950s and the early 1960s and to relate it to the Italian migrant experience of that time. The intended point of departure is the theoretical base proposed by Hamid Nacify (2001). Nacify presents a discourse on the cinematographic representation of the fundamental meaning of the exile/migrant experience. According to Nacify the sense of loss and of dislocation caused by the transition from the originating to the host country engenders representations of the diaspora by means of closed 
chronotopes expressed through claustrophobic images limited in space and time. ${ }^{3}$ He posits the construction of a liminal border space between the old and the new world in which the cinematographic image often becomes the autobiography of the diasporic collective which is in a state of constant flux. Further, Shohat and Stam consider that, like narrative, 'films can create $[\ldots]$ “..chronotopes”, materialising time and space, mediating between the historical and the discursive, providing specific environments where historically specific constellations of power are made visible' (Shohat and Stam 2003: 10). One could add these environments render visible chronotopes proper even to those, such as migrants, who are outside the power structure, since 'relative powerlessness generates a constant struggle to create an elusive authentic representation' (Shohat and Stam 2003, 10). These theoretical parameters can be linked to Homi Bhabha's concept of diasporic space, which designates a field existing between two boundaries that are continually being crossed and recrossed both physically and psychologically. In this context an immigrant inhabits a frontier land where the space and time of a different past is woven into that of the future, where habitual modes of thought and action are disrupted by the challenges of new realities. And it is precisely the challenges of new realities that inspired Giorgio Mangiamele’s initial cinematographic production.

As well as Clay, Mangiamele produced seven feature films between 1953 and 1970; at the end of the 1970s / beginning of the 1980s he also made four documentaries, and a short feature (Sapos) for the government of Papua New Guinea. All these productions are unequivocal examples of his skills as a director. His first five films produced between 1953 and 1963 present themes related to the Italian migration experience in Australia in the 1950s and view it in its contemporaneity and immediacy as an integral part of the existentialist condition of modern man. Mangiamele was the only Australian director consistently to treat migration themes at the time through potent claustrophobic images. These convey the stark reality of the Italian-Australian migration experience with its dislocation, alienation, and 
solitude, as well as the nostalgic recall of the home country. Emblematic characters struggle to find their bearings in a society that is unaccepting and in many aspects xenophobic.

Mangiamele's perceptions of migration are diametrically opposed to those found in the very few contemporary productions that deal with this theme. The documentary Mike and Stefani (Williams, 1951) portrays a process of migration to Australia wherein, once arrived, all problems will be solved. Three in a Million (Blackwood, 1959) adds a substantially happy ending to the migration experience: feelings of loneliness, alienation and exile are quickly and easily overcome. This unrealistic rose-tinted portrayal of the migration experience is continued in the feature They're a Weird Mob (Powell, 1966), based on John Patrick O’Grady's best-selling novel, which follows an Italian migrant (played by popular Italian actor Walter Chiari specially imported for the occasion) who rapidly, effortlessly and happily abandons his Italian heritage to assimilate mainstream Australian values. The success of this film stimulated interest in Australian government circles in the local fledgling film industry, eventually leading to funding programmes.

However some thirteen years before They're a Weird Mob brought Italian migration to the widespread attention of Australian cinema-goers, Mangiamele had produced the neorealism-oriented feature Il Contratto. The film remained incomplete due to lack of financial resources. There is no dialogue and the soundtrack consists only of the recitation in some scenes of significantly selected passages of Dante's Inferno, a few poems by late $19^{\text {th }}$ century Italian poets and some Italian popular melodies. ${ }^{4}$ Il Contratto is about the difficulties and the resulting anguish and frustration faced by the four protagonists who migrate to Australia by assisted passage on the undertaking that they accept any work assigned to them during the first three years in the country. On arrival they find the promised work does not exist since Australia is facing a recession (see Castles and Vasta 1992:105) so that instead of a rosy future they face a struggle for survival. That said, by the end of the film there are signs 
that their situation is slowly improving, though thanks to their fellow Italians rather than to Anglo-Celtic Australians.

Information about Unwanted (c.1957)—screenplay by Bob Clarke, cinematography and direction by Mangiamele-is only available from press comments that appeared at the time it was produced: no copies of the film seem to have survived. This short feature was made in less than two months and is 'the simple and woeful story of an illegal migrant [John] who arrives in Australia' (Anon. 1957). After having found work and become well integrated in his community, he meets a young and beautiful Australian girl (Margaret) and the two fall in love. Their love, however, is opposed by her parents and by Margaret's would-be Australian boyfriend Bruce, an ocker whose life vision is limited to drinking beer and betting on the horses and who, one evening when he is more drunk than usual, menaces the couple with a pistol, accidentally wounding Margaret. When the police arrive he manages to convince the couple that the wounding is John's doing (John is unable to defend himself because of his limited English) so that John is put on trial, found guilty and deported. The film, however, has a happy ending ambiguously poised between reality and illusion, strongly recalling the realismo magico and allegorical whimsy of such films as Miracolo a Milano (De Sica, 1950). As the ship is about to sail John's cabin door is flung open and Margaret appears ready to sail with him into an unknown future. When Unwanted was released Mangiamele stated that 'we are trying to create an Australian film industry for the new needs of Australian television that pays exorbitant sums of money for shoddy films imported from America and England by developing the talents of Old and New Australians' (Anon. 1957). Breaking the stranglehold of American distributors and establishing an Australian national film industry had become for Mangiamele a life mission (Mangiamele 2006a).

The Brothers (Mangiamele, 1958) focuses on how the new environment can seriously undermine the traditional values of the originating culture, and on how different individuals 
adopt different ways of 'making it' in the new country, critiquing Australian society's crassly materialistic values. Peter's elder brother succumbs to temptation and steals a large sum of money from his employer thus running the risk of ending up in jail. Peter (played by Ettore Siracusa), a humble newspaper seller, wishes to help his brother and attempts to steal money won by a drunk Australian at the races after a symbolic chase. However, the dramatic confrontation between Peter and the drunk leads Peter to give up the attempt: rather than making things easier, money 'only make people worse than they are.' As a result Peter's brother will end up in jail.

Two versions of The Spag were produced although only one released. In the first version (Spag 1) the protagonist Giovanni / Johnny, a young Italian automotive mechanic recently migrated to Australia, proves to be an excellent worker but becomes the target of discrimination and abuse in the workplace. He dies in saving an Australian boy from being run over by a drunk Australian van driver: the victim is the grandson of Johnny's landlady, who has on various occasions verbally derided him as a 'dago bastard'. The version released for screening (Spag 2), tells the story of Giovannino / Tony, a boy newspaper seller who is attempting to earn money to help his mother after the sudden death of his father. Although his mother passionately desires to return to Italy, Tony wants to remain in Australia, this despite being the target of three Australian youths who display characteristics of both ocker and bodgie types, and who call him 'dago kid' and beat him. While attempting to escape from his tormenters, Tony is run over by a drunk Australian van driver and killed.

Ninety-Nine Per cent is the only comedy produced by Mangiamele (Cutts 2003) and is to some extent based on a narrative style that recalls Pirandellian umorismo (Lampugnani 2006) but also contains significant elements of slapstick humour. It tells the story of Pino, a short and fat Italian widower, who decides to remarry when the principal of his son's school accuses him of not being able to look after his son properly. Given the scarcity of women 
willing to marry Italian migrants—a theme elaborated in the Italian comic film Bello onesto emigrato in Australia sposerebbe compaesana illibata (Zampa, 1971) starring Alberto Sordi and Claudia Cardinale and, later, in Love's Brother (Sardi, 2004)_Pino resorts to a matrimonial agency and is assured by the manager that he has a 99\% chance of making it with a beautiful tall blonde. When he calls on the lady in question she cruelly derides him. The likeable protagonist is left only with his son to console him.

Taken together the five films constitute a graphic representation of the many facets of the Italian migration experience, depicted as it was unfolding, and projected beyond its surface realities. In the 1950s Italian migration to Australia was at its peak and its protagonists not only had to face the difficulties of having to understand a new and strange environment as well as an unknown language but also of having to cope with discrimination and hostility (Castles and Vasta 1992: 104-119). Mangiamele depicts his migrant protagonists in situations where contact with the wider Australian community is extremely restricted, and where there is no possibility of cultural negotiation. In the main, working-class Italian migrants certainly did not enjoy the solidarity of their Australian counterparts and the minority of migrants who had trade or professional qualification found it extremely difficult, at times impossible, to have them recognized (Castles and Vasta 1992: 107). Another problem was the severe gender imbalance (far fewer Italian women emigrated with respect to men) and the reluctance of Australian women to marry Italian men (Castles and Vasta 1992: 111, 114).

With the exception of Peter (The Brothers), who is faced with the moral dilemma of choosing between doing the right thing and family loyalty-a strongly entrenched trope in films from the home country-Mangiamele's Italian characters can be considered as emblematic of this experience. The four protagonists of Il Contratto find that their expectations of striking it rich in the lucky country are not met, not only because of the unfavourable economic situation but also because of the bank's refusal to help. They are 
forced to make do as best they can. John (Unwanted) is not treated equitably by a premulticultural justice system that is not geared to cater for the culturally and linguistically diverse, while Giovanni (Spag 1) is subjected to discrimination in the workplace both by his fellow workers and the boss. A contributing factor to their problems is their lack of competency in the English language and the refusal on the part of Australians to accommodate this. Despite the support of his friend John and Mr. Brown's kindly disposition towards him, Tony (Spag 2) finds that his willingness to find ways to adjust to the mainstream is severely thwarted by his Australian peers. Mangiamele, however, goes beyond the 'sociological' reality to focus on the complex existential aspects of their diverse situations.

That is, as well as populating the liminal contact space in which Italian migrants operate, Mangiamele represents Australian characters through perceptions, attitudes and behavioural norms of 'the other side'. It is no accident that drunks are featured in three of the films, since the majority of Italian migrants considered Australian drinking habits and the endemic presence of drunks in the streets highly negative features of their new world. ${ }^{5}$ In Spag 1 and 2 it is a drunken van driver who kills Giovanni and Tony and then flees rather than face up to his responsibilities. The drunk in The Brothers acts both as the trigger to Peter's moral dilemma (it his careless display of the money won at the races that leads Peter to stalk and nearly killed him) but he is also instrumental in causing Peter to reconsider what he is about to do. In Ninety-Nine Per cent the stand-up confrontations between Pino and the drunk at the beginning and end of the film provide comic relief to 'lighten' the underlining pathos but also serves to highlight Pino’s dignity and humanity. In a sense the confrontations are also implicitly critical of Australian's denigration of CALD migrants, and, specifically, constitute a counter to the derision directed at Pino by the other characters, since here it is the drunk Australian who is clearly 'inferior'. 
Most of the other characters display a range of antagonistic attitudes as well as lack of negotiation towards CALD migrants, particularly in Spag 1 where hostility is expressed at a choral level. Giovanni's Australian co-workers deride him because he is a migrant, does not speak English, saves all his money to buy 'a great big house' (in reality he is also supporting his elderly mother in Italy), and because he always eats spaghetti; the landlady, her grandson and other inhabitants of the boarding house all deride him because he is a dago. Relatively few characters display willingness to assist the migrant in coming to terms with Australia. The English teacher and the nurse in Spag 1 display some understanding of Giovanni's difficulties but do not do anything concrete to help him. It is the 'educated' Australians in Spag 2 who are favourably disposed towards Tony. Mr James, the elderly landlord, always provides a friendly greeting and sometimes a tip (although never invites him into his house) while Tony's friend John (Spag 2), a university student, teaches him English, talks about Australia and Italy and attempts to protect him against the three bodgies.

It can be argued that the most dramatic and striking of Mangiamele’s migrant films are the two versions of The Spag. They provide a powerful visualisation of migrant alienation and marginalisation in Australia's inner-city areas. Spag 1, in particular, universalizes Australian attitudes towards CALD migrants in a highly critical manner. Both versions explore the potential for the development of brotherhood between Australians and CALD migrants which is however impeded by the presence of 'bad' elements that exclude the migrant, blocking any possibility of integration to the extent that both versions conclude with the death of the protagonist, signifying total exclusion.

Lampugnani claims that Spag 2:

[...] can be read on two levels: on the one hand the mimetic appraisal of the migrant's encounters with persecution, xenophobia or at best an apparent and superficial attitude of tolerance and, on the nosographical plane, the dream-like phantasy sequence of acceptance 
(and remorse) following the protagonist's death which may be identified with a conscious obsessive yearning for fulfillment on the biographical plane. (Lampugnani 2005: 59)

The case for a 'phantasy sequence of acceptance', if applied to the Australian characters, is somewhat problematic, since in both versions the protagonists are finally and utterly excluded by death and, despite generally displayed remorse, Giovanni's body is left alone on the asphalt, while it is John alone who bears the lifeless body of Tony. In both versions Mangiamele posits the ideal of a universal brotherhood among people united by a common humanity notwithstanding differences of race, culture and language, a theme poignantly highlighted in the voiceover to the final scene of Spag 1:

\footnotetext{
$[\ldots]$ he wasn't a useless man, he had much to live for [...] You call him a dago but he was a simple migrant. A man like you are a man and whom nobody tried to understand or give a helping hand, only because he couldn’t speak your own language. Yes, he had much to live for like every human being.
}

It is impossible, however, to achieve universal brotherhood in the temporality of Australia in the late 1950s / early 1960s. So whereas only five years after The Spag the antithetic and highly successful They're a Weird Mob broadcast its unrealistic message of easily and instantaneously achieved assimilation, for Mangiamele assimilation is a much more difficult and complex matter. Tony (Spag 2) is unhappy when the tickets for the return to Italy arrive. He seems more disposed to integrate than Giovanni (Spag 1) for whom, despite his attempts to fit in as best he can, integration is 'impossible' (see the scene with the English teacher) since he feels rejected by Australians who do not consider his humanity equal to theirs (thus demolishing the myth of Australian egalitarianism).

It seems somewhat strange that Lampugnani did not also analyse the first version of The Spag. Where Spag 2 contains conciliatory and hopeful overtones, Spag 1 presents a much 
more articulated critique of Australian society and its absolute refusal to accept the 'other'. There are, however, quite precise, even indispensable links between the two versions as well as with the other migrant films. These include close-up techniques in the images of temporality, in the claustrophobic depiction of space, and in the physical and psychological barriers that prevent the CALD migrant from participation. In both versions temporality is expressed through a strong sense of transitoriness. Giovanni's job is precarious-he is dismissed very easily_as is also his attendance at English language classes. There seems to be no real effort to help him with his learning difficulties-bearing in mind that Giovanni would probably have received only a very basic school education in Italy—and the room he rents seems transient in a temporal sense. Tony’s time in Australia also has a transient quality given that he and his mother will be provided with the chance to return to Italy despite Tony's desire to remain in Australia. His work as a paper boy also seems precarious given the harassment by the three bodgies. In the final analysis temporality is strongly marked by the moment in which the spaghetti is thrown to the ground, a moment that foreshadows the protagonists being thrown to the ground in the finale: they are destined to remain in Australia only for a short space of time, almost as if Australia represents a time of transition to the final mystery of life.

Australia also proves to be a time of transition for John in Unwanted and his deportation projects him into an uncertain but not altogether unhopeful future. In The Brothers temporality is marked by the moment when Peter decides not to hit the drunk Australian with the rock, thus putting aside the past tradition of family loyalty for the new social consciousness of the present. The superimposition of past and present is also apparent in the first part of Ninety-Nine Per cent where Pino’s practices—derived from the originating culture (for example, 'ethnic' food, the fanatical desire to accumulate money so that his son can receive a good education)—are contrasted by those of his son who wants to be like his 
Australian peers. Past and present, however, are bridged in the end when the son consoles Pino after the traumatic moment of derision. Although the sound track in some scenes of $I l$ Contratto are evocative of the nostalgic recall of a time past, temporality in the film seems essentially linear. The time from when the four protagonists step off the gangplank to when they finish work in their compatriot's market garden seems to mark, despite moments of loneliness and despair, a transition from old world past to potential integration in a new world present.

Liminal space is depicted in strikingly similar ways in the two versions of the Spag. In the closed environment of the workshop the Australian workers try to avoid Giovanni as much as possible and during breaks he sits in the far corner with only a worker of Italian parentage for company. Giovanni's small rented room is presented as claustrophobic and isolating, a poor and uncertain refuge from the hostility expressed by the landlady, her grandson and the Australian workers. The only positive moments of contact with Australians involve brief encounters with the patronising English teacher (in the constrained space of his room) and the nurse (in the workshop yard). In the few instances when Giovanni is represented in more open spaces there is a strong sense of liminality. One of the powerful images in the film appears after he is dismissed. He walks along the street with his back to the camera, a figure dressed in trousers that end above the ankles posturing resignation without hope, reminiscent of Gelsomina in La Strada (Fellini, 1954).

In Spag 2 space for Tony’s mother is also limiting and claustrophobic. She is always surrounded by walls and has no contact with Australians. All she wants after the death of her husband is to return to Italy. For Tony there is an apparently different dimension. The open space on the steps leading to the front door of his home presents a positive element since it is there that he talks to John and receives English lessons. Tony also has the space of Carlton streets where he does his work as a paper boy and where he can observe and make contact 
with Australians. However, this common and apparently liberating space is polluted and made constraining by the presence of the three ocker/bodgies and their threats, pursuits and beatings as also by other barriers that deny him full participation in Australian society: the shop windows; and the grate in the window of the house of Mr James who, despite displaying friendliness to Tony, retains a certain detachment, never inviting him to enter the house. But perhaps the most powerful images of liminal space are the yard in the automotive workshop (Spag 1) and the street (Spag 2) where the spaghetti is spilt onto the ground, a markedly symbolic sign of rejection. Images of leaves (most of the films) and newspapers (The Brothers, Spag 2) blown about by the wind, and the oranges scattered when Tony is thrown to the ground by one of the bodgies (Spag 2), can also be interpreted as functioning as symbols of non-acceptance in Australian space while the images of the ordered market garden in Il Contratto provide a contrast in their representation of Italian contadino space within the limiting constraints of Australian space.

An intricate play on space can be noted in Il Contratto. The opening scenes show a joyous linking of Italian space, represented by the ship, with the wide open area of Port Melbourne representing Australian space. This link is, however, quickly broken when the migrant characters are transported to the confining spaces of inner-city Melbourne where their lodgings, the bank and the barriers encountered in the streets severely limit their contact with mainstream Australia. The transition to the market garden on the outskirts of Melbourne is both constraining and liberating in that the characters are completely isolated from Australian space but find work and social contacts within their own small community. Paradoxically it is their isolation which brings them to earning the money that will potentially provide a new beginning in Australian space. In Ninety-Nine Percent Pino operates in limited confined spaces (the cafes and pubs where he sells his goods, his chaotic home space) and his attempts to 'break out' into wider Australian space (the streets, the matrimonial agency, the woman's 
apartment) are met by confrontation (the drunk in the streets), ironic patronisation (the matrimonial agency) and derision (the woman's apartment). It is only in the finale that the open space of an inner city park provides a point of union for him and his son.

Although O’Regan (1996) examines the work of later Italian-Australian directors such as Fabio Cavadini and Monica Pellizzari in his discussion of the social-diasporic problematic in Australian cinema, Mangiamele is completely ignored. It can be argued, however, that Mangiamele's portrayal of the migration experience is in fact a pioneering one. Migration and settlement appeared as sporadic minor themes in Australian national cinema somewhat later in features such as They're a Weird Mob, Silver City (Seale, 1984) and Looking for Alibrandi (Woods, 1999), films directed by non-Italian-Australians and which do not present views of the Italian immigration experience from within: They're a Weird Mob and Looking for Alibrandi, for example, assert the superiority of Australian culture over the culture of Italian migrants. ${ }^{6}$ By contrast, the work of Giorgio Mangiamele, and that of many subsequent Italian Australian film-makers (see Rando 2004: 206-26 and Rando 2005), constitutes a key-witness account of the immigration experience from within, critiquing the dominant culture, and countering mainstream Australian history. Although 'ethnic' film-makers do not usually present radical political agendas, at least not in the Australian context, they nevertheless often address a politics of interiority rarely addressed elsewhere, creating a space for the expression of minority-group ideas and values, and for an articulation of how the minority group interacts with the mainstream in specific times and spaces.

In this respect it is interesting to note that Mangiamele's negative, albeit realistic, interpretation of the migration experience was being created at the same time that both Australian and Italian government agencies were circulating propaganda about the great opportunities Australia offered. Mangiamele’s diasporic narratives therefore provide a counter-discursive perspective that both questions and undermines propagandistic 
constructions of Australia, and implicitly contests dominant notions of history and nation. For the CALD migrants in Mangiamele’s films there is little understanding, acceptance or justice, and Australia is certainly not a place where the outsider is given a 'fair go'. The representation of the immigration experience in these films demolishes many of the myths that traditionally have been understood to constitute an Australian sense of identity (egalitarianism, tolerance, fair play).

Mangiamele's output married a global perspective and an experimental cinema approach to local Australian subject matter and concerns. Influenced by Italian neo-realism, but also Eisenstein and the French impressionists, Mangiamele brought a pan-European modernist perspective to Australian cinema and an interest in what Quentin Turnour has described as ‘allegorical narrative, the Symbolist image and the filmed dream’ (2001). This was clearly not appreciated in the Australian cinema culture of the 1950s and the 1960s, though Scott Murray’s obituary for Mangiamele (2001) quotes one of the few contemporary Australian eulogies for Clay, from the Advocate: 'Mangiamele is one of the world's master craftsmen in the art of film, a man who really knows how to use a camera to tell a story and whose photography is a joy’. Giorgio Mangiamele’s role in the development of Australian cinematic culture during this period can be compared to Gino Nibbi's contribution to the development of Melbourne's art culture in the 1930s and 1940s (Rando 2004: 79), and Claudio Alcorso's contribution to modernist Australian design in the 1950s and 1960s, and to Australian opera in the 1960s and 1970s (see Talia 2001). But despite his pioneering role, throughout his lifetime Mangiamele received little assistance from institutions interested in supporting Australian cinema, and his work has been largely overlooked by Australian cinema critics and historians.

\section{References}

Anon. (1957), 'L’Indesiderato,’ La Rivista italiana, Melbourne, 20 May, no pag. 
Baxter, J. (1970), The Australian Cinema, Sydney: Angus and Robertson.

Cappiello, R. (2003), Oh Lucky Country (trans. Gaetano Rando), Sydney: Sydney University Press (Classic Australian Works series).

Castles, S. and Vasta, E. (1992), 'L'emigrazione italiana in Australia', in S. Castles, C. Alcorso, G. Rando and E. Vasta (eds), Italo-australiani. La popolazione di origine italiana in Australia, Turin: Edizioni della Fondazione Giovanni Agnelli, pp. 97-120.

Castro, A. (2000), ‘A Profile of Giorgio Mangiamele’, Senses of Cinema, 4, pp. 1-3.

Collins, F. and Davis, T. (c2004), Australian Cinema After Mabo, Cambridge: Cambridge University Press.

Conomos, J. (1992), 'Cultural Difference and Ethnicity in Australian Cinema,' Cinema papers, 90, pp. 10-15.

Cutts, G. (1992), ‘Giorgio Mangiamele’, Cinema Papers, 90, pp. 16-22.

Cutts, G. (2003), 'Some Notes on the Films of Giorgio Mangiamele,' http//www.innersense.com.au/mif/mangiamele_notes Accessed 3 October 2006.

Dermody, S. and Jacka E. (1987), The Screening of Australia, vol 1: Anatomy of a Film Industry, Sydney: Currency Press.

Dermody, S. and Jacka E. (1988), The Screening of Australia, vol 2: Anatomy of a National Cinema, Sydney: Currency Press.

Ditessa, R. (2001), ‘Mangiamele’s Last Interview’, Italy Down Under, 6, p.80.

Ferlito, F. (2006), Interview by Gaetondo Rando, Rome, 13 January.

Lampugnani, R. (2002), 'Envisioning the Italian Migrant Experience Down Under: Giorgio Mangiamele, Poet of the Image,’ Italian Historical Society Journal, 10:1, January-June, pp. 16-24.

(2005), 'Depicting the Italo-Australian Migrant Experience Down Under: Images of Estrangement in the Cinema of Giorgio Mangiamele’ in R. Wilson and S. Scarparo 
(eds), Studi d'Italianistica nell'Africa australe / Italian Studies in Southern Africa. Special issue: Representing Italian Diasporas in Australia: New Perspectives, 18:1, pp. $52-66$.

(2006), 'Comedy and Humour, Stereotypes and the Italian Migrant in Mangiamele's Ninety Nine Percent', Fulgor, 3:1, December, pp. 11-24.

Mangiamele, R. (2006a), Email communication with author, 11 September.

----- (2006b), Email communication with author, 17 September.

----- (2007), Email communication with author, 12 February.

Murray, S. (2001). 'Giorgio Mangiamele - Passionate Film-maker,' Age, 22 May.

----- (ed.) (1994), Australian Cinema, Sydney: Allen and Unwin in association with the Australian Film Commission.

Nacify, H. (2001), Accented Cinema: Exilic and Diasporic Film-making, Princeton: Princeton University Press.

O’Regan, T. (1996), Australian National Cinema. London and New York: Routledge.

Rando, G. (2004), Emigrazione e letteratura Il caso italoaustraliano, Cosenza: Luigi Pellegrini Editore.

-----. (2005), 'Mezzo secolo di cinema italoaustraliano: una prima retrospettiva,' Altreitalie, 30, January-June, pp. 160-166.

Also at http://www.italians-world.org/altreitalie/28_saggi1e.htm

Shohat, E. and Stam, R. (2003), 'Introduction', Multicultutalism, Postcoloniality and Transnational Media, New Brunswick: Rutgers University Press, pp. 1-17.

Stewart, J. (1984), An Encyclopaedia of Australian Film, Sydney: Reed Books.

Stratton, J. (1998), Race Daze: Australia in Identity Crisis, Sydney: Pluto Press. 
Talia, J. (2001), 'Passion for the Arts Drove Adventurous Life Down Under', Italy Down Under, 4, http://www.italydownunder.com.au/issuefour/index.html Accessed 3 May 2007.

Tuccio, S. (2005a), 'Giorgio Mangiamele: l'autore in/visibile’ in S. Tuccio (ed.), Sguardi australiani. Idee, immaginari e cinema degli antipodi, Le Mani: Genova, pp. 99-109.

----- (2005b), ‘Cinema agli antipodi. Conversazione con Claudia Mangiamele’, Sguardi australiani. Idee, immaginari e cinema degli antipodi, Le Mani: Genova, pp. 174-86.

Turner, G. (1994), Making it National: Nationalism and Australian Popular Culture, Sydney: Allen and Unwin.

Turnour, Q. (2001), 'Giorgio’, Senses of Cinema, 14, http://www.sensesofcinema.com/contents/01/14/contents.html Accessed 3 May 2007.

Verhoeven, D. (ed.) (1999), Twin Peeks: Australian and New Zealand Feature Films, Melbourne: Damned.

${ }^{1}$ Heartfelt thanks are due to Mrs Rosemary Mangiamene in particular, to Dr Franco Ferlito, Gino Moliterno, Quentin Turnour, Ettore Siracusa, Robert Garlick, Nigel Buesst, George Dixon, The National Film and Sound Archives (Canberra and Melbourne) and the Italian Historical Society (Carlton) for having greatly facilitated research through interviews and access to materials by and about Giorgio Mangiamele. Thanks are also due to the Faculty of Arts, University of Wollongong for having granted a period of study leave for this project. 
${ }^{2}$ Jedda had been taken to the Cannes Film Festival 'market' before Clay but was not in competition.

${ }^{3}$ According to Bakhtin the chronotope is the matrix where the principal sequences of time and space in a work of art intersect - that is where dialogues, meetings and happenings are created, where the ideas and passions of the protagonists are revealed. Bakhtin's theory of the chronotope is based on the idea that in a work of art spatial and temporal dimensions are inseparable as in Einstein's theory of relativity.

${ }^{4}$ The origins of the soundtrack found on existing copies of the film is something of a mystery. Mrs Rosemary Mangiamele has stated that a soundtrack was added when the film was screened at the ACMI (Australian Centre for the Moving Image) retrospective following Mangiamele's death in 2001: 'There was no soundtrack on the [copy of the] film for the screening, and I asked Virgilio Marciano to compile an audio tape of Italian music which accompanied the screening of the film, so the audience was not sitting in silence for the 93 minutes.' However, the copy available in the NFSA archives (Canberra) has a soundtrack for part of the film with Mangiamele singing and quoting passages from Dante’s Inferno. Quentin Turnour reported that 'what we can hear was no more than a guide track, rather than a final attempt. I can image that having some sort of sound — any sort—on the print may also reflect a trial printing with film sound in local labs-another hurdle [Mangiamele] couldn't overcome in that time and place and that this was partly due to the fact that at the time Australian postdubbing facilities were not up to Italian studio standards' (Mangiamele 2006b and 2007).

${ }^{5}$ This is also a commonly recurring theme in Italian Australian literature. In Rosa Cappiello’s novel Oh Lucky Country (2003), for example, drunkenness is posited to reveal metaphysical 
aspects of Australian society. Australians drink to blot out complexes, nostalgia and existential anguish, and their addiction to drink becomes a compensatory symbol of their lack of humanity and intellectual and social finesse.

${ }^{6}$ Migration and diaspora are, however, central themes in Italian-Australian cinema that developed from the 1970s when a new wave of directors began to create a corpus of cinematic production that constitutes one of the 'alternative' strands of Australian film culture, presenting not only an inside view of the Italian-Australian diasporic experience but also a view from the periphery of Australian society (see Rando 2004: 206-26; Rando 2005). Among the new wave were Ettore Siracusa, whose career as a film-maker began by working with Mangiamele, and Monica Pellizzari, who came to Mangiamele for assistance in the early stages of her career (Mangiamele 2006b). 